\title{
TEORETSKI POGLED NA RAZVOJNE STRUKTURE SLOVENSKEGA PODEŽELJA
}

\section{Marijan M. Klemenčič}

Oddelek za geografijo, Filozofska fakulteta, Aškerčeva 2, 1000 Ljubljana

e-mail: marijan.klemencic@guest.arnes.si

Izvirni znanstveni članek

COBISS 1.01

\section{Izvleček}

V prvem delu prispevka so predstavljeni teoretični pristopi in problemi, povezani s preučevanjem sodobnega podeželja, v drugem delu pa sledi poskus opredelitve odločilnih razvojnih dejavnikov in nosilnih struktur slovenskega podeželja skozi njihov razvoj po 2. svetovni vojni kot izhodišče za oblikovanje teoretično bolj poglobljenih konceptov v slovenski geografiji.

Ključne besede: podeželje, teorija, razvojne strukture, razvoj slovenskega podeželja.

\section{THEORETICAL VIEW ON THE DEVELOPMENT STRUCTURES OF SLOVENIAN RURAL SPACE}

\begin{abstract}
Theoretical concepts and research problems of contemporary rural space are presented in the first part of the article, following with the attempt of defining the crucial factors of development and basic structures of Slovenian rural space after the 2nd World War as a starting-point for defining theoretically more advanced concepts in Slovenian geography.
\end{abstract}

Key words: rural space, theory, development structures, development of slovenial rural space. 


\section{OPREDELITEV PROBLEMA}

Sodobne spremembe na podeželju označujeta hitrost in vztrajnost procesov na eni ter celovitost in soodvisnost sprememb na drugi strani. Te splošne poteze razvoja podeželja dobivajo od 90. let 20. stoletja z načrtnim posegom državnih oblasti v celovit razvoj podeželja v gospodarsko razvitem delu sveta nove poudarke. Države (posebno EU) so od pasivnega (kapitalistično-kolonialnega) odnosa do podeželja prešle k aktivnemu, razvojno naravnanemu odnosu. Osnovni razlog za takšen zasuk je povečano zanimanje mestnega prebivalstva za kakovosti, ki jih nudi podeželje, posebno na področju bivanja in rekreacije, pa tudi družbenih odnosov.

V zahodnoevropskih državah se je glavnina najintenzivnejšega družbenogospodarskega in posledično prostorskega razvoja v 20. stoletju osredotočila na mestna območja, kar je pripeljalo do poenostavitve podeželskih struktur; podeželje je moralo slediti grobim zahtevam kapitalističnega gospodarstva. Nasprotno pa je slovensko podeželje zaradi političnih usmeritev (zemljiški maksimum), zapoznele intenzivne in prostorsko relativno razpršene industrializacije, ki se ji je hitro pridružila motorizacija, vzdrževalo dokaj ugodno ravnovesje z mesti. V prvih povojnih desetletjih se je to odražalo v relativno visokem deležu na podeželju živečega prebivalstva, ki je tam zadovoljevalo precejšen del življenjskih potreb (pridelava hrane, osnovne oskrbne dejavnosti, zaposlitev).

Družbeni položaj podeželja se razkriva tudi v zanimanju stroke za njegove probleme. Značaj podeželja in celovitost njegovih problemov sta bila v zahodnoevropskih geografskih krogih deležna sorazmerno skromne pozornosti. Nasprotno pa je slovenska geografija večino svojih raziskovalnih prizadevanj usmerila v probleme podeželja. Takšno stanje pa se je bistveno spremenilo v 90. letih 20. stoletja. Močno povečano zanimanje za podeželje v zahodnoevropskih državah je vzpodbudilo teoretsko poglobljene razprave o značaju podeželja, ki pa žal niso našle ustreznega odmeva v slovenski geografiji.

$\mathrm{V}$ prispevku želim v prvem delu predstaviti teoretične pristope in probleme, povezane $\mathrm{s}$ preučevanjem sodobnega podeželja ter opozoriti na šibkost uporabe teoretičnih konceptov v preučevanju slovenskega podeželja. V drugem delu sledi poskus

opredelitve odločilnih razvojnih dejavnikov in nosilnih struktur slovenskega podeželja skozi njihov razvoj po 2. svetovni vojni kot izhodišče za oblikovanje teoretično bolj poglobljenih konceptov.

\section{TEORETSKI POGLEDI NA SODOBNO PODEŽELJE}

Zapletenost in prepletenost razvojnih dejavnikov podeželja otežuje oblikovanje teoretskega orodja, s katerim bi celovito predstavili podeželsko stvarnost. Zato v literaturi najdemo sicer lepo število teoretskih konceptov, ki pa osvetljujejo le del podeželske tematike, na primer gospodarsko (običajno kmetijsko), sociološko, kulturno, identitetno. Čeprav se posebno v anglosaški literature pojavljajo razprave o nujnosti "ruralnih študij", ki naj bi izpostavile posebnosti podeželja, pa obstajajo le posamični poskusi tovrstnih študij; 
dominantnost mest nad podeželjem se kaže tudi na raziskovalnem področju. Na drugi strani je razumljivo in logično, da se zaradi močnega povezovanja sveta in posledične soodvisnosti pri preučevanju podeželja vse bolj uporabljajo enotni pojmi, pristopi in predstave, ki jih lahko opredelimo kot "nova geografija" (Klemenčič, M. M., 2005). Tako so med sodobnimi raziskavami podeželja vsakdanja naslednja teoretična orodja:

- $\quad$ temeljni pojmi: podeželje, ruralnost, mestno-podeželski kontinuum;

- $\quad$ splošni geografski pojmi: prostor, kraj, življenjski prostor, teritorij, itn.;

- procesi: modernizacija, (sub)urbanizacija, globalizacija;

- $\quad$ najširše raziskovalne smeri: (post)strukturalizem, (post)modernizem;

- $\quad$ novi vidiki dojemanja podeželja: kultura, identiteta, mrežna struktura, multifunkcijskost, (post)produktivizem.

Zaradi obsežnosti tematike želimo opozoriti le na nekatere glavne značilnosti razvoja sodobnega podeželja in načine njegovega teoretičnega razumevanja ter razlage.

Sodobne spremembe podeželja opredeljujeta hitrost in vztrajnost ter celovitost in soodvisnost sprememb. Vzrok za hitrost in zapletenost sprememb je v pospešenem razvoju tehnologije, v družbenih reformah in vključitvi podeželja $\mathrm{v}$ globalne socialne in prostorske procese. Spremembe se najbolj pogosto označujejo s pojmom modernizacija podeželja, ki pa vsebuje tudi preobrazbo podeželske družbe in slabitev povezav med družbo in naravo. Omenjene globoke spremembe nekateri teoretiki postavljajo v kontekst postmodernizma, s katerim so se "urejenost, struktura in normativni ideali modernizma preoblikovali v svet, ki ga bolj označujejo tokovi, pretočnost in mnogoterost” (Woods, 2005, 19). Postmodernizem se namreč ne kaže le v fizični modernizaciji podeželja, ampak spodbuja spremembe v obnašanju in dojemanju ljudi, ki žive na podeželju in ga oblikujejo. S tem se nadaljuje zmanjševanje meja med mestnim in podeželskim. Še več, nove oblike in predstave o podeželskosti naj bi preusmerjale dojemanje podeželja kot prostorsko trdne entitete na podeželskost kot del družbene prakse. S tem v zvezi se pojavlja razmišljanje o podeželju kot o hibridnem prostoru (Woods, 2005, 154). Njegovo bistvo označujejo mrežna struktura, gibljiv (ang. fluid) prostor in niz zapletenih medsebojnih odnosov družbenih in naravnih bitnosti, kar skupaj ustvarja različne vrste podeželja.

Raznorodnost podeželske družbe in podeželskega prostora rojevata življenjske razlike, zaradi česar se je spremenila tudi simbolična oznaka podeželskosti. Podeželska socialna struktura je postala tako oddaljena od tradicionalnega dojemanja podeželja, da se govori o post ruralnosti (Cloke, 2006, 22) - "porabnik" podeželskosti naj bi dojemal podeželje kot neavtentično mešanico pomenov in simbolov. V skladu s tem gledanjem je podeželskost postala deteritorializirana; pomenski znaki in simboli podeželskosti so namreč postali vse bolj oddeljeni od njihovih pripadajočih geografskih prostorov.

Na prvi pogled precej drzna gledanja na značaj podeželja postanejo bolj domača ob trditvi Halfacreeja $(2005,46)$, da so prostorski učinki sodobnega kapitalizma usmerjeni v odstranjevanje starih geografskih razmejitev in meja, zato je prišlo do prostorske izgube elementov, ki s(m)o jih nekdaj smatrali za značilno podeželske in mestne.

Pospešeno vdiranje mestnih dejavnosti na podeželje in s tem oblikovanje vse bolj zapletenih družbenogospodarskih in prostorskih struktur sili raziskovalce $\mathrm{k}$ vedno novemu 
opredeljevanju vsebine podeželja. Cloke (2006) ugotavlja, da podeželje označuje mnogo socialnih prostorov, ki prekrivajo isto geografsko območje. Podeželje naj ne bi enostavno prevzemalo mestnih vrednot in oblik. Pri razumevanju vsebine podeželja si lahko pomagamo z naslednjimi teoretičnimi okviri (Cloke, 2006):

1. funkcijski koncept ruralnosti; le delno izrecno teoretični koncept, ki se le približuje konceptu ruralnosti (prevlada ekstenzivne rabe, naselja nižje oskrbne stopnje, notranje povezana skupnost);

2. politično-ekonomski koncepti; razlaga vsebine podeželja $\mathrm{v}$ okviru mednarodnega politično-gospodarskega razvoja;

3. Socialna zgradba ruralnosti; usmerjenost na postmodernistični in postrukturalni način razmišljanja, posebno glede vloge kulture v družbeno-prostorski stvarnosti.

Tektonske spremembe družbenogospodarskih razmer proti koncu 20. stoletja (globalizacija, postfordizem, razvoj telekomunikacij, politične spremembe, iskanje identitete, ekološki problemi) so tudi v preučevanje podeželja prinesle nove pristope, zlasti v okviru postrukturalizma in postmodernizma. Širina vsebine podeželja in njeno preoblikovanje v sodobnosti pa presegata pojasnjevalne zmožnosti omenjenih dveh konceptov. Iščejo se razlage za razumevanje temeljnih značilnosti in procesov na podeželju, ki sledijo poskusom razlage splošnih geografskih pojmov, kot so kraj, teritorij, regija (Klemenčič, M. M., 2005). Če je čas ob koncu 20. stoletja zaznamovala modernizacija podeželja (v slovenski geografski literaturi se za to stanje uporablja izraz urbanizacija podeželja), naj bi podeželje v vstopu v 21. stoletje zajel postmodernizem. Namesto velikih fizičnih sprememb naj bi prihajalo do sprememb v obnašanju in dojemanju podeželskega prebivalstva. Postmoderno podeželje je manj natančno opredeljeno in omejeno kot predhodno modernizirano podeželje. Isti avtor zatrjuje, da se je potrebno odvrniti od razumevanja ruralnosti kot prostorsko trdne entitete in se usmeriti na ruralnost kot družbeno prakso. Podeželje naj bi obravnavali kot hibridni prostor; to je prostor z nizom zapletenih medsebojnih odnosov družbenih in naravnih bitnosti. Pojem "hibridnosti" naj bi pripomogel k osvetlitvi pestrosti in dinamike podeželja. Bistvo pojma leži v nizu mrež, v katerih so različne bitnosti uvrščene na različne načine, kar ustvarja različne vrste podeželja. Usmerjenost na omrežja in "tekoče" (angl. fluid) prostore naj bi po mnenju Woodsa razbila predstave, da je določanje in razmejevanje podeželskih prostorov enostavno; nasprotno, povzročila naj bi celo nasprotujoča razumevanja procesov na podeželju.

Cloke (2006) še radikalizira Woodsovo gledanje na podeželje tako, da govori o "post ruralnosti", ki naj bi predstavljala neavtentično mešanico pomenov in simbolov. Gre za gledanje, da je ruralnost postala deteritorializirana, ker so pomenski znaki in simboli postali vse bolj oddeljeni od njihovih pripadajočih geografskih prostorov; govorimo lahko o določeni vrsti virtualne ruralnosti.

Dopodobnihugotovitev prihajaHalfacree(2006); v sodobnem kapitalizmu vididejavnika, ki odstranjuje stare geografske razmejitve, kar vodi k izgubi nekdaj značilnih podeželskih in mestnih prostorskih elementov. Podeželski materialni prostor in prostor podeželskih socialnih predstavitev naj bi obstajala le skozi dejavnost diskurzivnih součinkovanj. Podeželje naj bi se manifestiralo na tri načine:

- $\quad$ podeželje kot umišljenost; poskusi razlaganja podeželja v okviru poststrukturalističnega 
in lingvističnega koncepta;

- podeželje kot materialnost in predstava; klasična predstava podeželja kot območja s prevlado ekstenzivne rabe tal, majhnimi naselji in identitetno povezanimi skupnostmi;

- podeželje kot način ravnanja (prakse); prostor moramo obravnavati v času - prostor kot proces in proces $\mathrm{v}$ prostoru.

Halfacree si je zastavil nalogo, da oblikuje celovit model podeželja, ki ga je naslonil na Lefebvrejevo trozložno razumevanje prostorskosti. Kot izhodišče je opredelil naslednje elemente:

- prostorske dejavnosti (praksa); dejanja, tokovi, prenos in součinkovanja, kar je zaobseženo $\mathrm{v}$ družbenem prostoru, predstavlja rutinsko dejavnost in je po vsebini podobna konceptu lokalnosti;

- $\quad$ predstavitve prostora; formalne koncepcije prostora, ki jih izpeljujejo podjetniki, planerji in raziskovalci in so zato izmišljene in abstraktne;

- $\quad$ prostor predstavljanja; prostori se nanašajo na domačijski prostor, ki si ga na simboličen način prilaščajo domačini z oblikovanjem podob in simbolov.

Pomemben vidik podeželja, pa tudi vsake druge prostorske stvarnosti, je notranja čvrstost (trajnost). Pri tem je pomembno, do kakšne mere in na kakšen način so na lokalni ravni v podeželje vpleteni gospodarstvo, država in civilna družba. Halfacree (2006) predlaga tri značilnosti strukturirane podeželske skladnosti:

- $\quad$ skladnost in združenost; vsi elementi podeželja se skladajo na sorazmerno mehak, trden način, zato so formalne predstavitve podeželja enotne;

- protislovnost in razkosanost; kljub napetostim in protislovnostim med in znotraj podeželskih elementov obstaja splošna skladnost, v formalnih predstavitvah podeželskosti pa pogosto stopajo v ospredje različne prostorske prakse;

- $\quad$ kaotičnost in nepovezanost; podeželje obvladuje vsakodnevna življenja, čeprav med seboj niso povezana na ravni dojemanja in predstav; pomanjkanje lokalne notranje skladnosti, ki jih prinašajo temeljna nasprotja med ali znotraj podeželskih elementov, predstavlja potencialno razdiralne razvojne alternative, kar lahko razbije družbeno reprodukcijo.

Prihodnost podeželja naj bi se po Halfacreeju odvijala v okviru štirih prostorskih scenarijev.

1. Izrazit produktivizem. Vračanje na prostorski produktivizem, a sedaj v mnogo manj zmerni obliki. Prisoten je v delovanju agrobiznisa, pridelavi genetsko spremenjenih rastlin in živali ter v uporabi biotehnologije na splošno. Zemlja je v predstavah obravnavana kot izključno produktivistični vir, akumulacijska strategija.

2. Potrošniška idila. Je nasprotje izrazitemu produktivizmu. Jemlje in razvija ublažen tradicionalni moralni "pastoralizem” v okviru ideje skupnosti. Kmetijstvo je praviloma postavljeno v ozadje na račun potrošniško usmerjenih rekreacije, bivanja in migracij ("urbanizacija podeželja"). V ospredju teh dejavnosti naj bi bila "podeželska idila". Lokalna skladnost je zaradi različnih, večinoma vpeljanih (ne proizvedenih) dejavnosti kontradiktorna in nepovezana. 
3. Podcenjena podeželskost. Pri opredeljevanju razlik med podeželskim in mestnim prostorom v poznem kapitalizmu strokovnjaki ugotavljajo podcenjevanje podeželja; leto nadvladujejo nepodeželske dejavnosti, podeželju pa puščajo le duhovni obstoj, doživet skozi ljudski spomin, nostalgijo. Kjer je podeželskost še vedno živa, lahko pričakujemo kontradiktorno in nepovezano lokalno skladnost.

4. Radikalni pogledi. Radikalnost je mišljena tako, da se na podeželju skušajo izraziti bolj proizvedene kot vpeljane razlike; s tem bi se izzvala prostorska logika kapitalizma. Podeželje naj ne bi bilo le prostor prilaščanja, ampak tudi načina (alternativnega) življenja, ki izziva sodobno družbeno in gospodarsko pogubnost. Kmečka avtarkija, vaška skupnost in nekdanja tehnika niso cilj oživitve preteklega načina življenja, ampak izhodišče za razvoj oblik družbenega in gospodarskega življenja, različnega od predhodnega. Takšen lokalni podeželski razvoj si lahko predstavljamo kot decentraliziran in sorazmerno samooskrben način življenja, kot pestro domovanje, dostopno vsem, ki z vsakodnevnimi izkušnjami čutijo pomen lokalnosti in posameznika. Izziv radikalnim politikom je v tem, da za takšna območja zagotovijo dolgotrajnejši in trajen razvoj.

Nakazanih je le nekaj (celovitih) teoretskih izhodišč in pogledov na sedanji in možni bodoči razvoj podeželja za katere se zdi, da so usmerjeni v bistvo problematike podeželja gospodarsko najbolj razvitega dela sveta. Zaradi posebnosti razvoja (preskok dobršnega dela kapitalističnega razvoja) se je slovensko podeželje znašlo v sami konici razvojnih teženj sodobnega evropskega podeželja, zato je poznavanje tujih teoretskih izhodišč ne le dobrodošlo, ampak nujno za razumevanje in načrtovanje slovenskega podeželja.

\section{DOSEDANJEOBRAVNAVERAZVOJNIHSMERISLOVENSKEGA PODEŽELJA}

Slovensko podeželje obravnavajo številne geografske raziskave. Prevladujejo tiste, ki se ukvarjajo s posameznimi vidiki (demografski razvoj, razvoj naselij, kmetijski in okoljski problemi, razvoj turizma itn.), malo pa je takih, ki bi zajele celostno problematiko podeželja (Klemenčič, 1991; Klemenčič, M. M., 2002; Kladnik \& Ravbar, 2003; Klemenčič, M. M. in sod., 2005). Za starejše obdobje je treba omeniti Medvedov (1972) pregled dotedanjih preučevanj slovenskega podeželja, predvsem pa posvet o geografskih značilnostih preobrazbe slovenskega podeželja (ur. Peterle, 1982), na katerem je bila vsestransko osvetljena struktura slovenskega podeželja v obdobju najmočnejše preobrazbe. Posvet je bil pomemben predvsem zaradi prizadevanja, da bi se opredelila vsebina podeželja ter izpostavile njegove strukture in procesi. Na teoretičnem področju je bila v ospredju opredelitev vsebine podeželja, med ostalimi vprašanji pa izpostavimo urbanizacijo podeželja (Klemenčič, 1982), modernizacija, "mešan" način življenja, pa tudi poskus predvidevanja prihajajočih značilnosti in problemov podeželja ter njegovega pomena za celotno družbo (Jeršič, 1082). Glede na celovitost obravnavanih problemov in strokovno zavzetost udeležencev posvet predstavlja vrh dosedanjih obravnav slovenskega podeželja. Žal slovenska geografija ni izrabila dogodka kot izhodišča za teoretsko 
poglobljene raziskave in je zato močno zaostala za dosežki svetovne geografije podeželja.

Na kratko si oglejmo najpomembnejše ugotovitve o stanju slovenskega podeželja, kot so opredeljene v geografski literaturi na prelomu tisočetja. Zanimajo nas predvsem strukture in razvojni trendi, ki nakazujejo novo podobo slovenskega podeželja.

Za izhodišče se mi zdi potrebno vzeti $\mathrm{v}$ pretres prispevek nosilnega preučevalca slovenskega podeželja, Vladimirja Klemenčiča. V kratki a vsebinsko zgoščeni razpravi se avtor (1991) osredotoča na obravnavo tipov demografskih območij, ob tem pa naniza še številne druge pomembne vidike razvoja podeželja. Nosilni pomen naj bi imel policentrični razvoj s prostorsko razpršeno industrializacijo, ki je ustvarila zelo širok sloj dnevnih migrantov kot pomembnega dejavnika preobrazbe podeželja. Z njimi so se hitro povečevali mali obrtnoindustrijski obrati. Klemenčič izpostavlja kmetijsko politiko kot oviro za razvoj zasebnega tržnega kmetijstva in slabšanje agrarne strukture $\mathrm{z}$ odvzemom najboljše kmetijske zemlje v korist družbenih obratov. Omejevanje velikosti zasebnih kmetij je pospešilo drobljenje posesti in prehod vedno večjih površin $\mathrm{v}$ roke nekmečkega prebivalstva; pospešena gradnja počitniških bivališč je v dobršni meri posledica teh procesov. Drobljenje posesti in krčenje obsega kmetijskih površin je prispevalo h krčenju števila čistih kmečkih gospodinjstev in skokovitemu zmanjševanju števila od zemlje odvisnega prebivalstva. Na koncu Klemenčič dodaja močan vpliv odprtosti državne meje na preoblikovanje podeželja. Razprava je bila napisana v času, ko so se šele nakazovale bistvene spremembe na podeželju, zato nam lahko služi kot pomembno izhodišče za ugotavljanje pomena novega razvoja.

V najnovejši analizi Klemenčič (2005) poglablja in zaokrožuje ugotovitve, objavljene leta 1991. Proces preoblikovanja klasične statične agrarne družbe v kulturno pokrajino dinamične moderne družbe se je po mnenju Klemenčiča odvijal v treh fazah. Zelo na kratko povzemam značilnosti posameznih faz. Za prvo fazo do konca 2. svetovne vojne veljajo značilnosti klasične agrarne družbe. Druga faza do osamosvojitve Slovenije je z uvedbo mehanizacije prinesla optimalno izkoriščanje zemlje, posledično opuščanje obdelave manj primernih kmetijskih zemljišč, socialno preobrazbo kmečkega prebivalstva, spreminjanje zunanje podobe podeželja. Tretja faza prinaša velike spremembe v zunanji podobi podeželja zaradi prehoda v kapitalistično gospodarstvo in vstopanja Slovenije v EU. Podeželje je postalo preplet elementov klasičnega in sodobnega kmetijstva. Na osnovi takšnega razvoja naj bi se oblikovali trije pokrajinski tipi: območja mest in urbaniziranih obmestij, urbanizirano in stabilno podeželje ter ogroženo in odmirajoče podeželje. Med pereče probleme razvoja slovenskega podeželja Klemenčič izpostavlja zemljiško strukturo in neskladnost regionalne razvitosti Slovenije. Posebej je potrebno omeniti pomembno ugotovitev metodološkoteoretskega značaja, da le redke analize uporabljajo prostorsko (celovito) naravnane elemente strukture družbenega razvoja, ki bi upoštevale vse značilnosti in posebnosti slovenskega prostora.

Kladnik in Ravbar (2003) v uvodnem delu členitve slovenskega podeželja izpostavljata arhaičnost podeželske podobe, opuščanje obdelovalnih površin in ogozdovanje. Slovensko podeželje naj bi se postopoma preobražalo v pokrajino s sodobno, fleksibilno gospodarsko in socialno strukturo urbanega značaja. Avtorja navajata Drozga (1995), ki sodobne razvojne tokove podeželja razvršča $\mathrm{v}$ pet sklopov:

- $\quad$ družbene spremembe (zmanjšanje števila kmečkega prebivalstva, poslabšanje socialno- 
demografske strukture predvsem $\mathrm{v}$ smeri ostarevanja prebivalstva in praznenja odročnih naselij),

- $\quad$ gospodarske spremembe (zmanjševanje vloge kmetijstva, opuščanje obdelave zemlje, naselja postajajo gospodarsko neodvisna od bližnje okolice, pojavljajo se nove, predvsem oskrbne funkcije),

- morfološke spremembe (neplanska zasnova naselij, dvojnost naselij na stari in novi del),

- $\quad$ funkcijske spremembe (odmiranje funkcije gospodarskih poslopij, nov tip stanovanjske hiše, širjenje zelenic, parkirišč itn., prenos točk srečevanja iz starega vaškega jedra v nove soseske in izgubljanje identitete kraja),

- fiziognomske spremembe (razvrednotenje skladnosti vaške arhitekture z naravnim okoljem, nastajanje zmesi rustikalnega in novega).

Kladnik in Ravbar ocenjujeta, da "se najpomembnejši strukturni problemi odražajo v zmanjšanih možnostih prilagajanja načelom in standardom evropske kmetijske politike, pomanjkljivi konkurenčnosti, močni mednarodni konkurenci iz tradicionalnih kmetijskih, vendar po sodobnih kriterijih urejevanih podeželskih območij, odročnosti, ki ni naklonjena sodobnim razvojnim impulzom, upadanju gospodarskih investicij, izseljevanju, zlasti mladega prebivalstva, ki še dodatno poslabšuje že tako neugoden prebivalstveni razvoj, ipd.“ (Kladnik, Ravbar, 2003, 40).

\section{POVOJNI RAZVOJ DRUŽBENOGOSPODARSKIH STRUKTUR NA SLOVENSKEM PODEŽELJU}

Za podeželje gospodarsko razvitega sveta naj bi bilo po Woodsu (2005) značilno, da je kmetijska proizvodnja in izraba ostalih podeželskih virov skoraj v celoti tržno-kapitalističnega značaja; vse podeželje, razen najbolj zaostalih območij, je oskrbljeno z osnovno infrastrukturo; država je prevzela skrb za razvoj podeželja; podeželsko prebivalstvo je dovolj premožno, da polno izkorišča in razvija podeželske atribute; sredstva javnega obveščanja odločilno vplivajo na dojemanje podeželja.

Takšna ugotovitev v veliki meri velja tudi za slovensko podeželje. Razlika je v tem, da je do takšnega stanja prišlo po zelo različnih poteh, zaradi česar so temeljne strukture podeželja $\mathrm{v}$ obeh primerih zelo različne. Zahodnoevropsko podeželje se je razvijalo pod nenehnim silovitim delovanjem kapitalizma, medtem ko se je kapitalizem (tržna proizvodnja) na slovenskem podeželju uveljavljal le obrobno, v največji meri na družbenih posestvih.

Navajam le nekaj bistvenih usmerjenosti političnega sistema v povojni Jugoslaviji, ki so bile povsem različne od usmerjenosti parlamentarne demokracije in so odločilno vplivale na specifični družbenogospodarski in prostorski razvoj podeželja takratne Jugoslavije:

- zemljiški maksimum (10 ha),

- $\quad$ zatiranje privatnega kmetijstva (skoraj do 70. let 20. stoletja),

- dajanje prednosti družbenemu sektorju v kmetijstvu,

- $\quad$ izrazita usmerjenost $\mathrm{v}$ industrializacijo. 
Preglednica 1: Funkcijske značilnosti slovenskega podeželja po 2. svetovni vojni. Table 1: Functional characteristics of Slovenian rural space after the 2nd World War.

\begin{tabular}{|l|c|c|}
\hline & Temeljne funkcije & Strukturni znaki \\
\hline Agrarna doba & proizvodna & tipi \\
\hline Industrijska doba & proizvodno-bivalna & procesi \\
\hline Postindustrijska doba & $\begin{array}{c}\text { proizvodna, bivalna, rekreacijska, } \\
\text { okoljsko-varstvena }\end{array}$ & odnosi \\
\hline
\end{tabular}

Slovensko podeželje po drugi svetovni vojni usmerjajo trije temeljni procesi:

- $\quad$ industrializacija in posledično deagrarizacija ter doseljevanje v mesta;

- $\quad$ modernizacija, posebno motorizacija in z njo povezana dnevna migracija;

- $\quad$ terciarizacija, pospešena zrazvojem informacijske tehnologije in razpršeno koncentracijo poselitve in gospodarskih dejavnosti.

Preglednica 2: Razvoj proizvodno-socialne strukture slovenskega podeželja.

Table 2: Development of productive-social structure of Slovenian rural space.

\begin{tabular}{|l|l|l|l|}
\hline & Kmetijstvo & Industrija & Terciarni sektor \\
\hline Agrarna doba & $\begin{array}{l}\text { samooskrbno, delno tržna } \\
\text { proizvodnja }\end{array}$ & $\begin{array}{l}\text { obrtno-manufakturna } \\
\text { proizvodnja }\end{array}$ & $\begin{array}{l}\text { krošnjarstvo, gostinstvo, } \\
\text { prevozništvo }\end{array}$ \\
\hline Industrijska doba & $\begin{array}{l}\text { delitev na tržno } \\
\text { in samooskrbno } \\
\text { proizvodnjo, polkmečka } \\
\text { struktura }\end{array}$ & $\begin{array}{l}\text { prevlada delovno } \\
\text { intenzivne proizvodnje, } \\
\text { NKV, KV delavci }\end{array}$ & $\begin{array}{l}\text { šibka razvitost, razvoj } \\
\text { turizma }\end{array}$ \\
\hline Postindustrijska doba & $\begin{array}{l}\text { tržna proizvodnja, } \\
\text { ekološka pridelava, } \\
\text { vzdrževanje kulturne } \\
\text { pokrajine }\end{array}$ & podjetništvo & $\begin{array}{l}\text { razvoj storitvenih in } \\
\text { informacijskih dejavnosti }\end{array}$ \\
\hline
\end{tabular}

Skokovit razvoj družbeno-gospodarske in prostorske strukture je v zadnje pol stoletja pustil močne sledove: preostanke preteklosti iz agrarne dobe ter temeljne prostorske strukture iz industrijske dobe. V sedanjem obdobju, ki ga odločilno zaznamuje informacijska tehnologija, se uveljavljajo prostorske strukture, ki so mešanica obeh predhodnih obdobij (Klemenčič, M. M., 2003, 157). Pestrost in drobna razčlenjenost struktur slovenskega podeželja, kot posledica specifičnosti naravnih razmer in povojnega razvoja, postavljata slovensko podeželje v sam vrh sodobnega razvoja evropskega podeželja, ki teži k multifunkcijskosti in postproduktivizmu. V manjšem zaostanku, zlasti za skandinavskimi državami, pa je slovensko podeželje na področju kulture (lokalna identiteta, razvijanje lokalne kulture) in varstva okolja. To pa sta področji, ki zahtevata posebno razvojno skrb, tudi s primernim razvojem lokalne in pokrajinske samouprave. 
Preglednica 3: Družbeno-kulturni vidik razvoja slovenskega podeželja.

Table 3: Social-cultural aspect of Slovenian rural space.

\begin{tabular}{|l|l|}
\hline Agrarna doba & celovitost/enotnost dela in kulture \\
\hline Industrijska doba & prostorsko in socialno ločevanje dela in kulture \\
\hline Postindustrijska doba & $\begin{array}{l}\text { prevzemanje identitetno-kulturnih potez agrarne dobe v novi preobleki } \\
\text { in novi elementi:estetika, znanje/učenje, spoštljiv odnos do narave, } \\
\text { duhovnost - po socialnih skupinah }\end{array}$ \\
\hline
\end{tabular}

\section{KOMENTAR}

Pri preučevanju podeželja v Sloveniji se ni izrazito uveljavil noben celovit teoretični koncept. Dosedanje pristope bi lahko ocenili kot pragmatično-utilitarne, ki se naslanjajo na socialnogeografski in predstrukturalistični pristop. Prvi (Klemenčič, 1991; 2006) skuša biti kar najbolj celovit in problemski v dojemanju podeželja, zato poleg struktur v ospredje postavlja procese in funkcijski pristop. Pri drugem pristopu (Kladnik, Ravbar, 2003) so V ospredju zanimanja sestavine struktur (demografske, zaposlitvene, proizvodne, rabe tal, naravnih razmer), ki pa so obravnavane ločeno. To je posebno vidno pri tipologiji podeželja, ki je formalistična in zato ne odraža funkcijskih značilnosti ter razvojnih vidikov podeželja. Omeniti je potrebno še številne prispevke, ki obravnavajo podeželje z izrazito aplikativnega vidika (planerskega, okoljskega, kmetijskega, turističnega). Slovensko podeželje torej čaka na poglobljene bazične (teoretične) raziskave. Pri zmanjševanju zaostanka za teoretičnimi pristopi $\mathrm{k}$ preučevanju podeželja za tujino pa je slovenska geografija lahko inovativna predvsem pri tipologiji podeželja. Zgoščenost, prepletenost in zapletenost podeželskih struktur nam namreč nudi izredno priložnost (in hkrati težavnost) opredeljevanja (časovno-prostorskih) tipov podeželja.

Uporaba tujih teoretičnih spoznanj je nujna zaradi enega razloga: vsebujejo zgoščena znanja, ki jih lahko uporabimo kot izhodišče za naše delo. Vse prevečkrat se dogaja, da se takšna spoznanja prevzemajo nekritično; najslabše pa je, da se jih sploh ne upošteva.

Poleg bolj poglobljenega teoretičnega pristopa k preučevanju podeželja je potrebno temeljito pretresti osnovne pojme, predvsem vsebino podeželja, suburbanizacije in urbanizacije podeželja in s tem meje med temi območji. Kljub posebnostim slovenskega podeželja (številna majhna naselja oz. razpršena poselitev, drobna in razdrobljena zemljiška struktura, močan in trajen pritisk mestnega prebivalstva) ni mogoče opravičiti prevelike samovolje pri opredeljevanju vsebine omenjenih pojmov $\mathrm{v}$ primerjavi z vsebino teh pojmov, kot jih razumejo v tujini. Izstopajoč primer je uporaba pojma urbanizacija podeželja, ki bi ga lahko primerjali z angleškim izrazom counterurbanization. Uporabniki slovenskega izraza nikjer ne pojasnijo njegove vsebine, zato so možne zelo različne razlage. S semantičnega vidika naj bi šlo za proces oblikovanja mest (urbanizacija) na podeželju, torej za dovolj velika naselja, za njihov mestni videz, mestne funkcije, mestni način življenja. Seveda je dejansko stanje daleč od takšnega razumevanja vsebine pojma. Na angleškem govornem področju jasno ločijo tri, vsebinsko različne pojme: urbanization (rast in nastanek mest), suburbanization (fizično 
širjenje mest, praviloma brez mestnih funkcij) in counterurbanization (preseljevanje mestnega prebivalstva na podeželje).

Podobno je zugotavljanjem razmerja med mestom in podeželjem, ki nima le teoretičnega, temveč tudi zelo pomemben praktični pomen. S korenitimi družbenogospodarskimi in političnimi spremembami v 90. letih 20. stoletja se je sicer vloga mest povečala (oskrbne, izobraževalne, rekreacijske dejavnosti), a je hkrati tudi podeželje pridobilo na pomenu kot območje z visoko stopnjo kakovosti življenja ter nudenja širokega stika s kulturno pokrajino in naravnim okoljem. Zaradi šibke gospodarske in demografske moči pa se podeželju ne uspeva enakopravno vključiti v lasten gospodarski razvoj oziroma v učinkovito izkoriščenje številnih virov. Mesta kot središča moči in odločanja agresivno vstopajo v upravljanje s podeželskimi viri; tako se potrjuje teza o trajni nadvladi mest nad podeželjem (Klemenčič, M. M., 1982).

Neizogibno dejstvo je, da nove družbenogospodarske razmere in njihovi prostorski učinki zahtevajo bistvene spremembe v načinu gledanja in razumevanja sodobnega (slovenskega) podeželja.

\section{Literatura}

Cloke, P., 2006. Conceptualizing rurality. V: Handbook of Rural Studies (ur. Cloke, P., Marsden, T., Mooney, P.), str. 18-28. Sage Publications.

Drozg, V., 1995. Morfologija vaških naselij v Sloveniji. Geographica Slovenica 27. Inštitut za geografijo, Ljubljana.

Halfacree, K., 2006. Rural space: constructing a three-fold architecture. V: Handbook of Rural Studies (ur. Cloke, P., Marsden, T., Mooney, P.), str. 44-62. Sage Publications.

Jeršič, M., 1982. Večfunkcionalni pomen našega podeželja. V: Geografske značilnosti slovenskega podeželja. GDS, str. 142-150.

Kladnik, D., Ravbar, M., 2003. Členitev slovenskega podeželja. Založba ZRC, Ljubljana.

Klemenčič, M. M., 1982. Nekatera teoretska izhodišča pri proučevanju podeželja. V: Geografske značilnosti preobrazbe slovenskega podeželja, str. 23-30. GDS, Ljubljana.

Klemenčič, M. M. (ur.), 2002. Podeželje na prelomu tisočletja: izzivi in problemi (Dela 17). Oddelek za geografijo Filozofske fakultete Univerze v Ljubljani.

Klemenčič, M. M., 2003. Civilizacijske razvojne stopnje in razvojni problemi obrobnih območij v Sloveniji. V: Priložnosti in možnosti regionalnih struktur na poti k združeni Evropi (Dela 19). Oddelek za geografijo, FF, Ljubljana, str. 153-164.

Klemenčič, M. M., 2005. Regija in regionalna struktura Slovenije. V: Geografski pogledi na regionalni razvoj (Dela 23). Oddelek za geografijo, Filozofska fakulteta, Ljubljana, str. 5-58.

Klemenčič, M. M., Lampič, B., Perpar, A., Potočnik Slavič, I., Slabe, A., 2005. Strukturni problemi in razvojni izzivi slovenskega podeželja $\mathrm{v}$ evropski razsežnosti. Končno poročilo ciljnega raziskovalnega programa: Konkurenčnost Slovenije 2001-2006. Oddelek za geografijo Filozofske fakultete, Biotehniška fakulteta, Inštitut za trajnostni razvoj, 169 str.

Klemenčič, V., 1982. Urbanizacija in deagrarizacija ter izraba zemlje za proizvodnjo hrane. V: Geografske značilnosti preobrazbe slovenskega podeželja. GDS, str. 41-48. 
Klemenčič, V., 1991. Tendence spreminjanja slovenskega podeželja. Geografski vestnik 63, str. $25-40$.

Klemenčič, V., 2005. Poskus opredelitve sodobnih problemov razvoja kulturne pokrajine slovenskega podeželja. V: Regionalno planiranje in regionalni razvoj med teorijo in prakso (Dela 24). Oddelek za geografijo, FF, Ljubljana, str. 171-184.

Medved, J., 1972. O geografskem proučevanju slovenske podeželske pokrajine. Geografski vestnik 44, str. 91-113.

Peterle, L. (ur.), 1982. Geografske značilnosti preobrazbe slovenskega podeželja. Gradivo za posvetovanje geografov ob 60-letnici Geografskega društva Slovenije. Ljubljana.

Terluin, I. J., 2001. Rural regions in the EU. Exploring differences in economic development. Nederlandse Geografische Studies 289, Utrecht/Groningen.

Woods, M., 2005. Rural geography. Processes, Responses and Experiences in Rural Restructuring. Sage Publications.

\title{
THEORETICAL VIEW ON THE DEVELOPMENT STRUCTURES OF SLOVENIAN RURAL SPACE
}

\begin{abstract}
Summary
Rural space is traditionally one of the most important research areas of Slovenian geographers. Due to quick and intensive changes of countryside the structures, processes and typologies have been the main research goals. The social geographic concept, initiated by Vladimir Klemenčič, has prevailed. Despite of the processes connected with a declaration of independence, introducing democracy and capitalist economy, that gave rise new dynamics and relations in the countryside, the old research concepts did not changed because the majority of researchers had found new special interests in ecological problems, tourism, regional planning and GIS.

Development of rural space in Slovenia after the 2nd World War has took place in specific political and economical conditions, marked by the following features:

- upper size of agricultural land (10 ha) for a private farm estate, determined by law;

- $\quad$ depress of private sector of agriculture by the state (till 70th in the 20th century);

- $\quad$ favourising state agricultural estates;

- $\quad$ very intensive industrialization.

Specific face of Slovenian countryside (50\% of inhabitants living outside the towns, nearly 6000 dispersed settlements, small and prevailing part-time farms, only $5 \%$ of agricultural population, intensive influence of urban population) have caused phenomena known as post-productivistic agriculture, postmodernity, political-economic approach, sociocultural approach, endogenous development, farm diversification, organic farming, paternalism, protected areas, selling the countryside, symbolic countryside, teleworking, etc. Namely, the most part of Slovenian countryside has overcome the era of capitalism. Small farmers were not able to organize market oriented production; through the part-time farming part of them
\end{abstract}


have abandoned farming or have been oriented to ecological farming, the others had succed to enlarge their farms organizing intensive market production.

Extremely differentiated Slovenian countryside of natural, economic and social features, intensive contacts of the rural population with towns (employment, services, education, entertainment) and vice versa (tourism, recreation, investments) offers the scholars great opportunity for empirical and theoretical studies; it could be treated as a laboratory for modern researches of rurality. 